\title{
Folk perceptions and patterns of use of orchid species in Benin, West Africa
}

\author{
Received: 2017-08-12; revised: 2017-09-30; accepted: 2017-02-22
}

\author{
Eméline Sêssi Pélagie Assédé1,2,3*, Chabi Adéyèmi Marc Sylvestre Djagoun ${ }^{1}$, Akomian Fortuné Azihou ${ }^{1}$, Meryas \\ Dègbémabou Kouton ${ }^{1}$, Yannick Senakpon Caleb Gogan ${ }^{4}$, Coert Johannes Geldenhuys ${ }^{3}$, Paxie Wanangwa Chir- \\ wa $^{3}$ and Brice Augustin Sinsin ${ }^{1}$ \\ ${ }^{1}$ Laboratoire d'Ecologie Appliquée, Faculté des Sciences Agronomiques, Université d'Abomey-Calavi, 01 BP 526, Abomey- \\ Calavi, Benin \\ ${ }^{2}$ Faculté d'Agronomie, Université de Parakou, BP 123, Parakou, Benin \\ ${ }^{3}$ Department of Plant \& Soil Sciences, University of Pretoria, Hatfield Pretoria 0028, South Africa \\ ${ }^{4}$ Faculté des Lettres, Arts et Sciences Humaines, Département de Géographie, Université d'Abomey-Calavi, BP 248, Allada, \\ Bénin \\ * Corresponding author: E-mail address: assedeemeline@gmail.com
}

\begin{abstract}
Summary: In Benin, people have a rich ethnobotanical knowledge of plant species, reflecting the cultural and ecological diversity of their environment. Several studies were focused on the question of how valuable are plant species for local communities. However, there has been very little research interest in the orchid species in spite of the importance of orchids in the livelihood of the local people. This study examined the use and differences in knowledge of local people of orchids in the Sudanian zone of Benin. An ethnobotanical study was conducted amongst the four main socio-economic and ethnic groups from six villages around the Pendjari Biosphere Reserve in Benin. One hundred and sixty people participated in this study. Data were gathered using semi-structured individual interviews and analysed using quantitative ethnobotanical methods. 29 different types of use were recorded and can be grouped into four main use categories: medicinal, veterinary, spiritual and food. There were differences in orchid utilization among the ethnic groups, gender and age. The knowledge of orchid uses was significantly affected by the ethnic group and the age of the respondent. Unlike young educated generations, most adults and elders, especially women, had a more comprehensive knowledge of orchid uses. Calyptrochilum christianum, the most used orchid, was mentioned in more than $50 \%$ of the types of orchid use. The Gourmantché and Waama tribe had more knowledge on orchid use whereas the Berba tribe had less knowledge. Three orchid species (Habenaria cirrhata, Eulophia horsfallii and Nervilia bicarinata) were reported as food. Orchids had low use value ranging from 0.01 (Eulophia spp) to 0.2 (C. christianum). The controlled access to the biosphere reserve and rural exodus can explain the lack of indigenous knowledge transfer of orchid use and value from elders to the young generation.
\end{abstract}

Key words: orchid, use value, traditional ecological knowledge, conservation

\section{Connaissances endogènes et usages des orchidées au Bénin, Afrique de l'Ouest}

Résumé: Au Bénin, les connaissances ethnobotaniques sont riches et variées, reflétant la diversité culturelle et écologique en place. De nombreuses études ont porté sur la question de l'utilité des plantes pour les communautés locales. Cependant, peu de travaux ce sont intéressés aux orchidées, malgré leur importance pour le bien-être des populations locales. Cette étude a examiné l'importance et la variation des connaissances locales sur l'usage des orchidées dans la zone soudanienne au Bénin. Une étude ethnobotanique a été conduite dans les quatre principaux groupes socioéconomiques et ethniques représentés par six villages autour de la Réserve de Biosphère de la Pendjari. Cent soixante personnes ont été enquêtées. Les données ont été recueillies à l'aide d'entrevues individuelles semi-structurées et analysées suivant les méthodes ethnobotaniques quantitatives. Au total, 29 différents types d'usages ont été enregistrées et peuvent être regroupées en quatre catégories: médecine, vétérinaire, spirituel et alimentaire. Il y a une variation des usages faits des orchidées aussi bien suivant les groupes ethniques, le genre que de l'âge. Le niveau de connaissance des usages faits des orchidées est significativement influencé par le groupe ethnique et l'âge du répondant. Contrairement aux jeunes générations scolarisées, la plupart des adultes et personnes âgées, en particulier les femmes, ont une plus grande connaissance des usages possible des orchidées. Calyptrochilum christianum, l'orchidée la plus utilisée, a été mentionnée dans plus de 50\% des types d'usages. Les Gourmantché et les Waama ont plus de connaissances sur l'utilisation des orchidées tandis que les Berba en ont moins. Trois espèces d'orchidées (Habenaria cirrhata, Eulophia horsfallii et Nervilia bicarinata) ont été rapportées comme utilisées dans l'alimentation. Les orchidées en générale ont une faible valeur d'usage, valeurs allant de 0,01 (Eulophia spp) à 0,2 (C. christianum). L'accès contrôlé à la réserve de biosphère et l'exode rural pourraient expliquer la rupture apparente du transfert des savoirs sur les usages et valeur des orchidées des anciens aux jeunes générations.

Mots clés: orchidée, valeur d'usage, connaissances écologiques traditionnelles, conservation

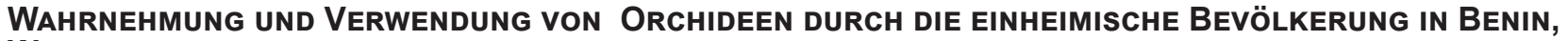 WESTAFRIKA}

Zusammenfassung: In Benin haben die Menschen ein reiches ethnobotanisches Wissen über, das die kulturelle und ökologische Vielfalt ihrer Umwelt widerspiegelt. Mehrere Studien befassten sich mit der Frage, wie wertvoll Pflanzenarten für lo- 
kale Gemeinschaften sind. Trotz der Bedeutung der Orchideen für den Lebensunterhalt der lokalen Bevölkerung gab es aber nur wenig Forschungsinteresse an den Orchideenarten. Die vorliegende Studie untersuchte die Unterschiede im Gebrauch und im Wissen der lokalen Leute von Orchideen in der sudanischen Zone von Benin. Die Studie wurde unter den vier wichtigsten sozioökonomischen und ethnischen Gruppen aus sechs Dörfern rund um das Biosphärenreservat Pendjari in Benin durchgeführt. Einhundertsechzig Personen nahmen an dieser Studie teil. Die Daten wurden mit Hilfe von semi-strukturierten Einzelinterviews erhoben und mittels quantitativer ethnobotanischer Methoden analysiert. 29 verschiedene Anwendungsarten wurden erfasst und können in vier Hauptnutzungskategorien unterteilt werden: Arzneimittel, Veterinärmedizin, Spirituelles und Lebensmittel. Es gab Unterschiede in der Verwendung von Orchideen unter den ethnischen Gruppen, Geschlecht und Alter. Das Wissen über die Verwendung von Orchideen wurde maßgeblich von der ethnischen Gruppe und dem Alter der Befragten beeinflusst. Anders als junge gebildete Generationen hatten die meisten Erwachsenen und Ältesten, insbesondere Frauen, ein umfassenderes Wissen über die Verwendung von Orchideen. Calyptrochilum christianum, die am häufigsten verwendete Orchidee, wurde in mehr als 50\% der Orchideenarten erwähnt. Der Stamm der Gourmantché und Waama hatte mehr Wissen über die Verwendung von Orchideen, während der Berba Stamm weniger Wissen besaß. Drei Orchideenarten (Habenaria cirrhata, Eulophia horsfallii und Nervilia bicarinata) wurden als Nahrung gemeldet. Orchideen hatten einen niedrigen Nutzwert im Bereich von 0,01 (Eulophia spp) bis 0,2 (C. christianum). Der kontrollierte Zugang zum Biosphärenreservat und die Landflucht können den Mangel an Weitergabe des Wissens der Älteren über die Orchideennutzung und deren Wert des Wissens an die jüngere Generation erklären.

Schlagworte: Orchideen, Nutzwert, traditionelles ökologisches Wissen, Naturschutz

\section{INTRODUCTION}

Biodiversity conservation measures are strengthened by traditional knowledge (Medhi \& Chakrabarti 2009, ParrotTA \& Trosper 2012). Traditional knowledge is thus an important factor for sustainability of natural resource management (GADGIL et al. 2000, BARROw et al. 2002). Orchids are herbaceous plants (TIWARI et al. 2012) which can be terrestrial, epiphytic or saprophytic (ACHARYA \& ROKAYA 2010). They belong to the Orchidaceae, an exceptionally diverse family and one of the largest and highly evolved families of flowering plants (HuYNH et al. 2009, ACHARYA et al. 2011, KANT et al. 2012). The Orchid family shows a high phenotypic diversity. Orchids are abundant in tropical rainforests and areas with relatively stable climates (GRAVENDEEL et al. 2004, DRESSLER 2005). They are mostly known for their beautiful flowers (CAKOvA 2013), making them a source of great economic value in the horticultural industry (HAMISY 2007, KASULO et al. 2009). In addition to their ornamental and ecological importance, orchids are also known for their medicinal use (NYOMORA 2005, Hamisy 2007, Dash et al. 2008, JALAL et al. 2008, Deb et al. 2009, Kasulo et al. 2009, Behera et al. 2013, PANT \& Raskoti 2013, Subedi et al. 2013). Orchid molecules were reported as important in reducing fevers, increasing the white blood cell count, and functioning as antimalarial and anti-cancer agents (TIWARI et al. 2012). In India, Eulophia herbacea Lindl. and Habenaria marginata Colebr. were respectively used to treat Rheumatism and Mental deficiency (TIWARI et al. 2012). During the last decade, several studies focused on the ecology and ethnobotanical knowledge of orchids (JUILLET 2006, JALAL et al. 2008, Kasulo et al. 2009, ACharya et al. 2011, Johnson 2012, ABe \& OhtAni 2013, Behera et al. 2013, BAYMAN et al. 2016).

Reports covering management and socio-economic aspects included the unsustainable harvesting (HEMLEY 1994, DAVENPORT \& NdAngalasi 2003, Vogt-Schilb et al. 2015), habitat fragmentation (NEwMAN 2009, JoHNSON 2012, KANT et al. 2012), economic pressure, and poor investment in design and implementation of forest management. Other concerns mentioned include inadequate legislation on sustained non-timber resource exploitation, lack of sufficient knowledge about the resources (GUEDJE et al. 2003) and community-based management of orchids (MEDHI \& CHAKRABARTI 2009, REIMER \& WALter 2013). Since the abun- dance and distribution ranges of many terrestrial orchids have largely declined (SUBEDI et al. 2013, VoGT-SCHILB et al. 2015), sustainable conservation of the wild orchids is universally of interest (NEwman 2009). This is especially important in order to protect the valuable orchid species in their natural habitat as orchids are very sensitive to ecological disturbances (JOHNSON 2012).

Previously, most of the studies focused on Asian orchid species (Pemberton et al. 2008, Acharya et al. 2011, LeE 2011); and on the Africa continent, mostly on the eastern and southern regions (JOHNSON 1996, MARTIN \& JOHNSON 2007, Peter \& Johnson 2014), with little emphasis on the West African ecosystems. Interests of scientists in Benin mainly covered the distribution range, demography, genetics and morphotype variability of indigenous fruit tree species (Assogbadjo 2006, Gaoue 2008, EkuÉ 2009, AvocÈvou 2011, FAndohan 2011, GouwaKinNou 2011, Koura 2013, VinotogbÉ et al. 2014). There has been very little interest in the orchid group in spite of their importance in the livelihood of local populations (SANFORD 1971, BERHAUt 1967, AkoÈgninou et al. 2006, Lisowski 2009, FANDOHAN 2011). Given the importance of the orchids to the local population, and the unique climatic and habitat conditions of West African savannas (OuÉDraOgo 2009, NACOUlma 2012, AssÉDÉ 2014), a preliminary study capitalizing on the indigenous knowledge on the orchid species was warranted in order to devise some conservation actions on the species.

In order to account for variability within and among ethnobotanical knowledge, the factors such as gender, age, ethnicity, profession, religion and cultural beliefs were highlighted in previous studies in Benin (Assogbadjo et al. 2008, Vodouhê et al. 2009, FANDOHAn et al. 2010, GouwAKINNOU et al. 2011, HouesSOU et al. 2012) and other countries (Grassi et al. 2004, Leakey et al. 2000, MuOK 2005, Pieroni et al. 2015). Thus, understanding the importance of orchids for local populations has to include such parameters.

In this study, we document the traditional knowledge of the orchid species in West Africa and provide managers with information required for implementing a sustainable and inclusive conservation program for these ecologically and economically important plant species. Specifically, we aim: (1) to analyze the traditional knowledge and use of orchid species among ethnical groups, (2) to determine the cultural 
importance of orchid species, (3) to identify the main factors that affect the knowledge of orchid species.

\section{Methods}

\subsection{Study area}

The research was conducted in the north-western part of the Republic of Benin (Figure 1) around the Pendjari Biosphere Reserve (PBR) in the Atakora Province. The area is the most disadvantaged area in Republic of Benin with the majority of people being poor, or vulnerable to poverty (ADÉGBIDI et al. 1999, MARTIN 2000). The PBR is surrounded by 20 villages (estimated at 30,000 inhabitants) with the people practising subsistence agriculture (mainly yams, maize, sorghum) as main activity, and livestock husbandry (CENAGREF 2016). The local population depends on the resources from the reserve and thus have extensive knowledge of the natural resources of the area (DJossa et al. 2008). The climatic regime is tropical with a unimodal rainfall with five month dry period (November-March). The mean annual rainfall is $1,000 \mathrm{~mm}$ with a mean temperature of $25-33^{\circ} \mathrm{C}$ (CENAGREF 2016). The vegetation of the Sudanian zone is dominated by savannas with patches of woodlands and gallery forests. The main tree species include Terminalia avicennioides, Combretum collinum, Crossopteryx febrifuga, Anogeissus leiocarpa, Khaya senegalensis, Burkea africana, Detarium microcarpum, Gardenia spp and Acacia spp.

\subsection{Sampling design and data collection}

In 2015, a study was undertaken, in collaboration with local leaders with experience and interest in indigenous plant uses, to develop a check list of different orchid species inside the protected area and its surroundings (AssÉDÉ et al. 2017). That check list was used to design and develop a photo guide to assist in species identification. The scientific names of orchid species were checked, using The Plant List (www.theplantlist.com). Representative individuals of each recorded species were sampled and conserved in the National Herbarium of the Republic of Benin. Traditional leaders in the study area were contacted for permission before the surveys were conducted. The study included the four main socio-economic and ethnic groups (Gourmantché, Waama, Berba, Fulani) from six villages (Tanougou, Sangou, Nanébou, Bournissou, Dassari, Tiélé) around the PBR (Fig. 1). The survey focused on the head of the household as our sampling unit. Twenty men and 20 women were interviewed in each ethnic group across the sampled villages, translating into 160 respondents (Table 1). Both qualitative and quantitative methods were used to collect data (FANDOHAN et al. 2010). In order to triangulate the information from the survey, three techniques (questionnaire; semi-structured interviews and group meetings) (after BLEss et al. 2013) were used to collect the data on orchid use. During interviews, a clear photo guideline showing the different parts of each orchid species, as well as a fresh sample, was used. Open-ended questions were asked about the plants used in the area. The respondents were asked to describe the use of each orchid species and its plant parts (roots, leaves, fruit and whole plant). The vernacular name of each orchid was also recorded.

\subsection{Data analysis}

\subsubsection{Knowledge and uses of orchids across ethnic groups}

The data were first arranged according to their category of use. The Multiple Correspondence Analysis (MCA) was used to disentangle the pattern of relationships between the orchid species and their use by the local people. MCA is a multivariate method analyzing the systematic patterns of variation of nominal categorical variables comprising
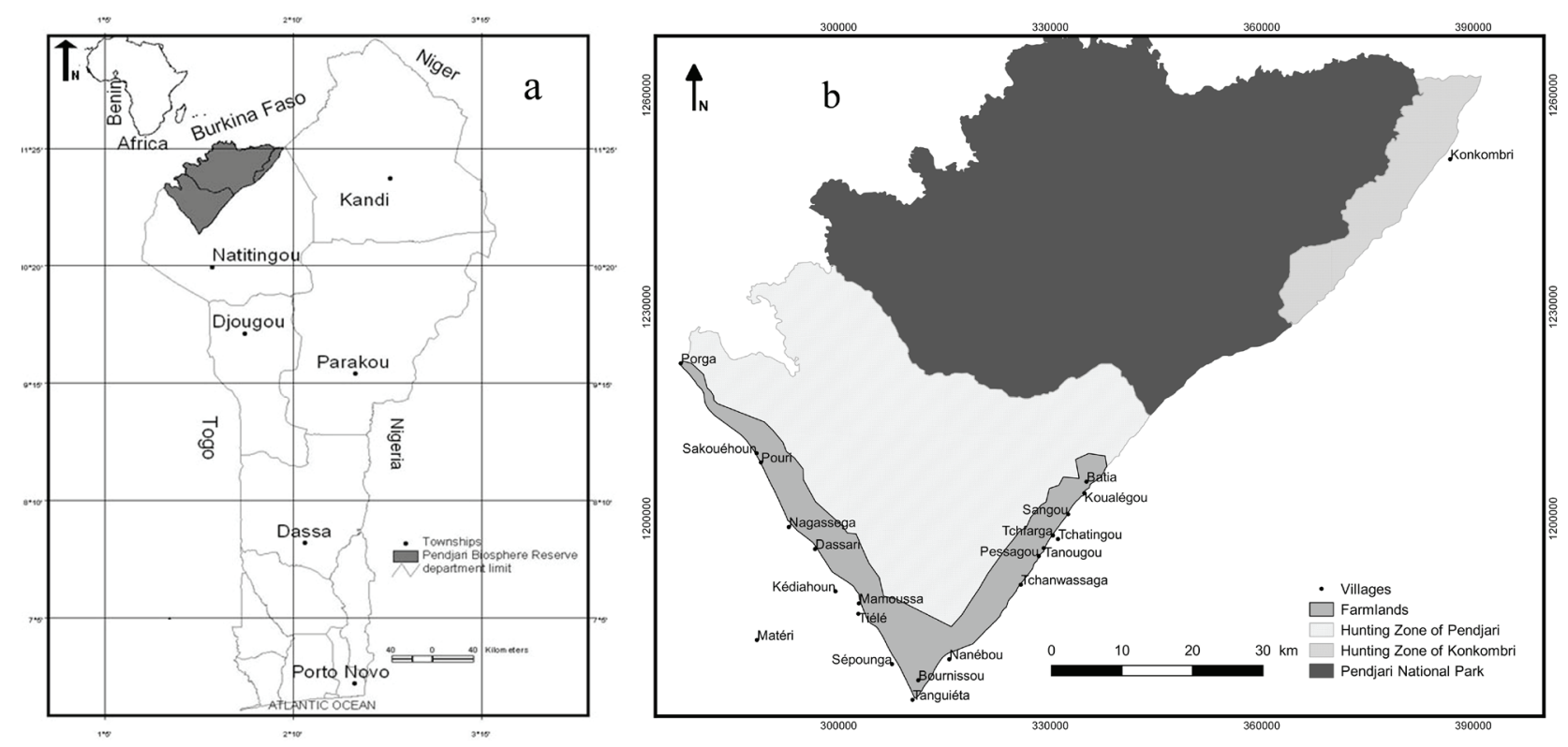

Fig. 1: Study area/milieu d'étude: (a) map of the Republic of Benin showing position of the Pendjari Biosphere Reserve (PBR)/ carte de la République du Bénin montrant la position de la Réserve de Biosphère de la Pendjari; (b) map of the PBR and the surrounding villages/ carte de la PBR et des villages environnants. 
Table 1: Characteristics of respondents in terms of number of participants per age, ethnic and gender / Charactéristiques des enquêtés en term de participants suivant l'âge, l'ethnic et le genre.

\begin{tabular}{|l|r|r|r|r|r|r|r|r|r|}
\hline & \multicolumn{2}{|c|}{ Berba } & \multicolumn{2}{c|}{ Fulani } & \multicolumn{2}{c|}{ Gourmantche } & \multicolumn{2}{c|}{ Waama } & Total \\
\hline Respondent class & $\mathrm{M}$ & $\mathrm{W}$ & $\mathrm{M}$ & $\mathrm{W}$ & $\mathrm{M}$ & $\mathrm{W}$ & $\mathrm{M}$ & $\mathrm{W}$ & \\
\hline Adult (<40 years) & 6 & 8 & 8 & 9 & 2 & 6 & 6 & 6 & 51 \\
\hline Adult (40-60 years) & 7 & 6 & 7 & 6 & 9 & 7 & 7 & 7 & 56 \\
\hline Old ( $\geq \mathbf{6 0}$ years) & 7 & 6 & 5 & 5 & 9 & 7 & 7 & 7 & 53 \\
\hline Total & 20 & 20 & 20 & 20 & 20 & 20 & 20 & 20 & 160 \\
\hline
\end{tabular}

$\mathrm{M}=$ men, $\mathrm{W}=$ women.

several levels. Each of these levels was coded as a binary variable. The analysis was performed on the respondents having knowledge on orchid species, described by seven categorical dependent variables : gender (male and female), age ( $\leq 40,40-60$ and $\geq 60$ years), education (educated and non-educated), ethnic group (Berba, Waama, Gourmantché, Fulani), use (medicinal, veterinary, spiritual, food), the part used (leaves, fruit, root, whole plant) and orchid species (Habenaria schimperiana, H. cirrhata, Eulophia guineensis, Nervilia kotschyi, Calyptrochilum christianum; only species with at least two categories of use were included in the analysis). The section of the old respondents ( $\geq 60$ years) was considered while the adults were subdivided into two subclasses (young: $\leq 40$ years and mature: $40-60$ years) to test if young people have less knowledge about orchids. The packages FactoMineR and ggplot2 of R3.3.1 (R Core Team 2014) were used.

\subsubsection{Cultural importance of orchid species}

The importance of the orchid species was assessed using the cultural importance index (CIs), computed for each orchid species in each category of use (medicinal, spiritual, veterinary and food) and in total (CI). The CIs was defined as the sum of the proportion of informants that mention each species use (TARdío \& Pardo-De-Santayana 2008, Sujarwoa \& Canevab 2016). The $\mathrm{CI}$ is the sum of the $\left(\mathrm{CI}_{\mathrm{s}}\right)$ for the four categories of use.

$$
\mathrm{CI}_{\mathrm{s}}=\sum_{\mathrm{u}=\mathrm{u} 1}^{\mathrm{NC}} \sum_{\mathrm{i}=\mathrm{i} 1}^{\mathrm{N}} \frac{\mathrm{URui}}{\mathrm{N}}
$$

$\mathrm{UR}_{\mathrm{ui}}$ was the number of informants 'i' who mentioned the use-category ' $\mathrm{u}$ ' for the species ' $\mathrm{s}$ ' and $\mathrm{N}$ was the total number of informants involved in the study. The theoretical maximum value of the CIs was the total number of different use-categories, reached in the unlikely case that all the informants would mention the use of the orchid species in all the use-categories (medicinal, spiritual, veterinary and food) of the study (TARdío \& PARdo-DE-Santayana 2008).

\subsubsection{Factors affecting the folk knowledge of orchid spe- cies}

Knowledge of orchid species was quantified as the number of uses cited by each interviewee. This response variable is typically discrete. Because count data in ecology are often overdispersed (VER HoEF \& Boveng 2007), the appropriate probability model was selected by comparing Poisson regression, quasi-Poisson regression and negative binomi- al regression based on a diagnostic plot of the empirical fit of the variance (using averaged squared residuals) to mean relationship. The negative binomial was a better fit to the overall variance-mean relationship. Therefore, the negative binomial regression was used to assess the influence of age, gender (female and male), education (educated and non-educated) and ethnic group (Waama, Fulani, Gourmantché and Berba) on folk knowledge of orchid species. It allowed for the modelling of a wide range of count response variables by one or more continuous or binary independent variables (predictor variables) (HıLв 2011). Among the predictors, only age is a continuous variable. So, a reference category was set up for each of the other predictors: female for gender, Berba for ethnic groups and educated for education. Analyses were performed using 'glm.nb' function from the MASS package of the software R 3.3.1 (R Core Team 2014).

\section{Results}

\subsection{Knowledge and uses of orchid across ethnic groups}

\subsubsection{List of recorded orchid species and their uses}

Twelve orchid species were recorded: Calyptrochilum christyanum (Rchb.f.), Cyrtorchis arcuate (Lindl.) Schltr., Eulophia spp, Eulophia guineensis Lindl., Eulophia horsfallii (Bateman) Summerh., Habenaria cirrhata (Lindl.) Rchb. f., Habenaria filicornis Lindl., Habenaria schimperiana Hochst. ex A.Rich., Nervilia bicarinata (Blume) Schltr., Nervilia kotschyi (Rchb.f.) Schltr., Platycoryne paludosa (Lindl.) Rolfe, Plectrelminthus caudatus (Lindl.) Summerh.. Overall, 29 different types of use were mentioned for the orchid species recorded used in this study and grouped into four main use categories: medicinal, food, veterinary and spiritual (Tables 2). Calyptrochilum christyanum, the most common epiphytic orchids was the only one used for medicinal, veterinary and spiritual purposes. It was mentioned in more than $50 \%$ of the types of orchid use. Used to treat painful menstrual cycle of the women and chicken diseases, C. christyanum was also reported to present antimalarial properties.

\subsubsection{Knowledge on orchid species according to the eth- nic groups}

From this study, $66.7 \%$ of the orchid species were known and used by local people. H. filicornis, P. paludosa, P. caudatus and $C$. arcuata were not identified by local people. About half (56.25\%) of the respondents knew and used at 
Table 2: Category of use, specific uses and vernacular names of orchid species per ethnic groups / Catégories d'usage, usages spécifiques et noms en langues vernaculaires des espèces d'orchidées par groupe ethnique.

\begin{tabular}{|c|c|c|c|c|}
\hline $\begin{array}{l}\text { Category } \\
\text { of use }\end{array}$ & Orchid species $^{1}$ & Vernacular name ${ }^{2}$ & $\begin{array}{l}\text { Ethnic } \\
\text { groups }\end{array}$ & Specific use \\
\hline \multirow{17}{*}{ Medicine } & \multirow{3}{*}{ Calyptrochilum christianum } & Kognialé/Otingbamo & Gourmantche & $\begin{array}{l}\text { Painful menstruation, Speed up walk } \\
\text { of baby, Swollen feet }\end{array}$ \\
\hline & & Kouayouri & Berba & $\begin{array}{l}\text { Malaria, Snake bite, Speed up walk } \\
\text { of baby }\end{array}$ \\
\hline & & Tiwahounga/Tiwaanga & Waama & Faith disease, Speed up walk for baby \\
\hline & \multirow{4}{*}{ Eulophia guineensis } & Tipotchatchari & Gourmantche & Swollen feet \\
\hline & & Koukoadatouwo & Berba & Cough \\
\hline & & Tigankouga & Waama & Stomach-ache \\
\hline & & Albatcha/Douhoundouho & Fulani & Fever, Stomach-ache \\
\hline & \multirow{2}{*}{ Eulophia sp } & Koukoadatou/Minansoari & Berba & Cough, Laxative \\
\hline & & Bissifabitibou & Waama & Speed up walk of baby \\
\hline & Habenaria cirrhata & Balasa & Fulani & Bracing \\
\hline & Habenaria schimperiana & Monmongué & Fulani & Eyesight \\
\hline & \multirow{4}{*}{ Nervilia bicarinata } & Yinpaye & Gourmantche & Fever \\
\hline & & Yinpaye & Berba & Muscle pain \\
\hline & & Yinpaye & Waama & Stomach-ache \\
\hline & & Loérehé/Taibè & Fulani & To urinate well/Jaundice \\
\hline & \multirow[t]{2}{*}{ Nervilia kostchyi } & Tipotchatchari & Gourmantche & Painful menstruation \\
\hline & & Léguédia/Bodi & Fulani & Cough, Stomach-ache \\
\hline \multirow{5}{*}{ Spiritual } & \multirow{2}{*}{ Calyptrochilum christianum } & \begin{tabular}{|l|} 
Tiwahounga/Tiwaanga \\
\end{tabular} & Waama & Luck, Power of prophecy \\
\hline & & Wiriwinou & Fulani & Power of disappearance \\
\hline & Eulophia guineensis & Potatiya & Waama & Against the twin spirits \\
\hline & \multirow[b]{2}{*}{ Nervilia bicarinata } & Pouri-gnan & Berba & Power of prophecy \\
\hline & & Yinpaye & Waama & $\begin{array}{l}\text { Against the spirit of a deceased, } \\
\text { witchcraft, against the twin spirits }\end{array}$ \\
\hline \multirow{5}{*}{ Food } & Eulophia horsfallii & Nadiahun & Berba & Sauce \\
\hline & \multirow{3}{*}{ Habenaria cirrhata } & Tikordjatoubli & Waama & Sauce \\
\hline & & Tikpingouandé/Tikordjatoubli & Gourmantche & Sauce \\
\hline & & Balasa & Fulani & Sauce \\
\hline & Nervilia bicarinata & Yinpaye & Gourmantche & Sauce \\
\hline \multirow{2}{*}{ Veterinary } & Calyptrochilum christianum & Kognialé/Otingbamo & Gourmantche & Chicken disease \\
\hline & Habenaria cirrhata & Bouboahoun & Berba & Chicken disease \\
\hline
\end{tabular}

${ }^{1}$ Scientific names follow/Les noms scientifiques suivent The Plant List (www.theplantlist.com); ${ }^{2}$ Vernacular names written were confirmed by the educated respondents and the National Herbarium/Les noms en langues vernaculaires ont été confirmés par les enquêtés instruits et l'Herbier National.

least one of the recorded orchid species. They were dominated by the Gourmantché (33.7\%) and Waama (33.6\%) ethnic groups. The local names of orchids varied among the ethnic groups and the specific uses (Table 2). The Fulani and Waama reported each $31 \%$ of the specific uses of orchid species. The Gourmantché and Berba were aware of respectively $34.5 \%$ and $21 \%$.

\subsubsection{Relationship between orchid species use pattern and ethnic groups}

Figure 2 presents the results of the MCA. The contours lines express the density of the respondents. The variables age and education are the most correlated with axis $1(\mathrm{r}=0.7$ and 0.6 respectively), while the variables gender, use and ethnic are the most correlated with axis 2 (respectively $r=$
0.6, 0.5 and 0.7). Most of the respondents were not educated. The knowledge of orchid species varied among educational status, age, gender and ethnic group of respondents. From the surveyed ethnic groups, non-educated, mature and old people (40 to more than 50 years old) and women had more knowledge of orchids (Fig. 2). The women used more of the orchids in medicine while the men (more than 60 years old) used them for spiritual and veterinary purposes. Most of them were not educated. In the Fulani group, the knowledge of orchids was more recorded with women of 40-60 years old. They used the root and fruit of E. guineensis in medicine to treat several diseases. C. christianum was both used in veterinary (by the Gourmantché) and for spiritual purposes (by the Berba). The Berba also used N. kostchyi for spiritual purposes. From the recorded orchids, only 


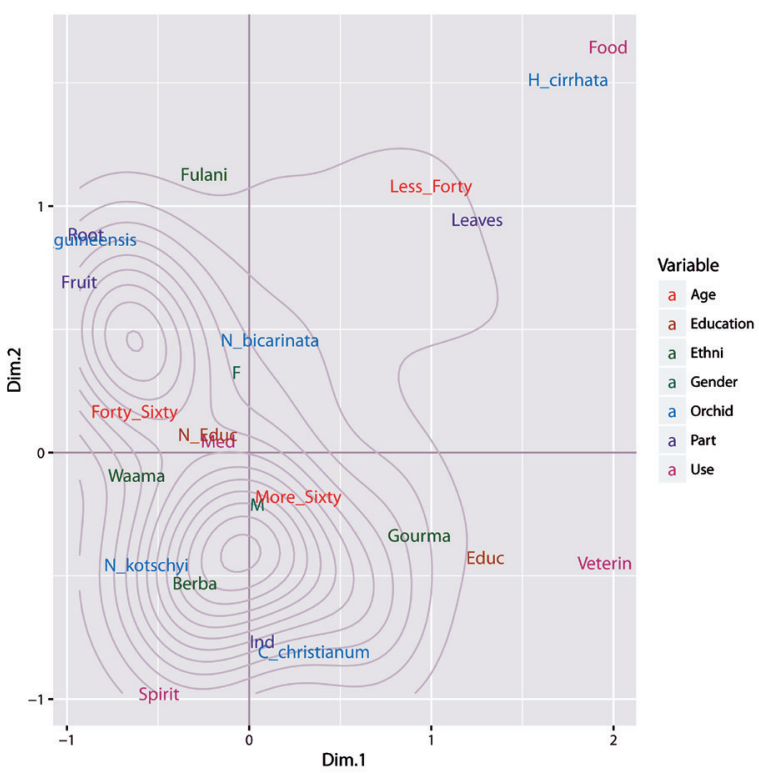

Fig. 2: Multiple Component Analysis of uses of Orchid species. Projection on the two dimensions (Dim.1 and Dim.2). The proportion of explained inertia was $62.4 \%$. C_christianum $=$ Calyptrochilum christyanum; $N$ kotschyi $=$ Nervilia kotschyi $E$ guineensis $=$ Eulophia guineensis $;$ H cirrata $=$ Habenaria cirrhata; Forty fifty $=40$ to 50 years old ; More fifty $=$ More than 50 years old; Less_forty = less than 40 years old; Gour$\mathrm{ma}=$ Gourmantche; Veterin = Veterinary; Med = Medicine Spirit = Spiritual; N Educ $=$ not educated; Educ $=$ Educated Ind $=$ Individual; $\mathrm{M}=\mathrm{Men} ; \mathrm{F}=$ women; Gray line $=$ density curves of the respondents. / Analyse en composants multiples des usages des espèces d'orchidées. Projection sur les deux axes (axe.1 et axe.2). La proportion d'inertie expliquée est $62,4 \%$. C_christianum = Calyptrochilum christyanum; $N$ kotschyi $=$ Nervilia kotschyi; E guineensis = Eulophia guineensis; $H$ _cirrata $=$ Habenaria cirrhata $;$ Forty_fifty $=40$ à 50 ans; More_fifty = plus de 50 ans; Less_forty $=$ moins de 40 ans; Gourma = Gourmantche; Veterin = Vétérinaire; Med = Médecine; Spirit $=$ Spirituelle; $\mathrm{N}$ Educ $=$ non instruits; Educ $=$ instruits; Ind $=$ Individus; $\bar{M}=$ Hommes; $F=$ Femmes; Gray line = Courbe de densité des enquêtés.

H. cirrhata, E. horsfallii and N. bicarinata were reported as food (Table 2) and mainly by the young Gourmantché ethnic group (Fig. 2). They are also the most educated, but with less knowledge of orchid species uses.

\subsection{Cultural Importance Index Value of orchid species}

Table 3 shows the contribution of each category of use to the total cultural importance index (CI) of the orchid spe- cies. Orchid species were mainly used for medicine and spiritual purposes by the respondents. They were not really used as food by most ethnic groups. Calyptrochilum christianum, represented the orchid with the most cultural significance according to the CI index (Table 3). The species had the highest CIs in medicinal use-category $(0.17)$, as well as for the total CI (respectively 0.2). Habenaria schimperiana and Eulophia horsfallii were the orchids with the least cultural importance according to the respondents.

\subsection{Factors affecting the knowledges of orchid species}

Two variables were significant in determining indigenous knowledge on orchid species (Table 4). The estimate associated with the variable age is positive; meaning that more people get older, more their knowledge on orchid species increases. Similarly, the estimate associated with the ethnic group Waama is positive and significant. So, people from the ethnic group Waama have more knowledge on orchid species than people from the reference ethnic group Berba. In the opposite, the estimates associated with the ethnic groups Gourmantché and Fulani are not significant. People belonging to these ethnic groups have similar knowledge on orchid species as the reference ethnic group Berba. As far as the variable gender is concerned, the estimate is not significant meaning that knowledge on orchid species did not vary between sexes. Finally, the estimate associate with the education is not significant. Thus, there is not a significant difference between knowledge of formal education and illiterates' people on orchid species.

\section{Discussion}

\subsection{Knowledges and Cultural Value of Orchid Species Across Ethnic Groups}

The study found significant ethnic and age variation in the knowledge and value of the uses of orchids by different socio-cultural groups around the Pendjari Biosphere Reserve (PBR). Such inter-ethnic differences have been reported elsewhere in Benin, including the Ottamari and Dendi with regards to the baobab (Adansonia digitate L.) tree (DE CALUwÉ et al. 2009) and the Fulani and Gourmantché with regards to the tamarind (Tamarindus indica L.) tree (FAN-

Table 3: Cultural importance index (CI) value of orchid species, with the CIs component of the category of use / Valeur de l'indice d'importance culturelle (CI) des espèces d'orchidées, avec la composante CIs de la catégorie d'usage.

\begin{tabular}{|c|c|c|c|c|c|}
\hline \multirow[t]{2}{*}{ Orchid species } & \multicolumn{4}{|c|}{ Category of uses (CIs) } & \multirow[t]{2}{*}{ Total CI } \\
\hline & Veterinary & Medicinal & Spiritual & Food & \\
\hline Calyptrochilum christianum & 0.01 & 0.17 & 0.02 & 0 & 0.2 \\
\hline Nervilia kostchyi & 0 & 0.04 & 0.06 & 0 & 0.1 \\
\hline Eulophia guineensis & 0 & 0.09 & 0.01 & 0 & 0.1 \\
\hline Nervillia bicarinata & 0 & 0.06 & 0.01 & 0.02 & 0.09 \\
\hline Habenaria cirrhata & 0.01 & 0.01 & 0 & 0.03 & 0.05 \\
\hline Eulophia spp & 0 & 0.03 & 0 & 0 & 0.03 \\
\hline Habenaria schimperiana & 0 & 0.01 & 0 & 0 & 0.01 \\
\hline Eulophia horsfallii & 0 & 0 & 0 & 0.01 & 0.01 \\
\hline Total & 0.02 & 0.41 & 0.1 & 0.06 & \\
\hline
\end{tabular}


Table 4: Coefficients from negative binomial regression / Coefficients de la régression binomiale négative.

\begin{tabular}{|l|l|l|l|l|}
\hline & Estimate & Std. Error & z value & $\operatorname{Pr}(>|\mathbf{z}|)$ \\
\hline (Intercept) & -3.92 & 0.92 & -4.26 & $<0.0001^{* * *}$ \\
\hline Gender $=$ Male $^{1}$ & 0.35 & 0.28 & 1.22 & 0.2200 \\
\hline Age & 0.04 & 0.01 & 2.93 & $0.0030^{* *}$ \\
\hline Ethnic group Gourmantche & & 0.43 & 1.85 & 0.0600 \\
\hline Ethnic group Waama $^{2}$ & 0.79 & 0.40 & 3.78 & $0.0002^{* * *}$ \\
\hline Ethnic group Fulani $^{2}$ & 1.52 & 0.45 & 0.59 & 0.5500 \\
\hline${\text { Education level }=\text { Not Educated }^{3}}^{2}$ & 0.26 & 0.46 & 1.08 & 0.2800 \\
\hline
\end{tabular}

z: statistic of Fisher / statistique de Fisher; Pr: probability of z / Probabilité z; Std. Error: Standard error / erreur standard; Gender M: Gender male / genre masculin.

$1:$ Reference group $=$ Female

2: Reference group $=$ Berba

3: Reference group $=$ Educated

DOHAN et al. 2010). More than sixty percent of inventoried orchid species were really known by the local population. In fact, some orchids recorded in savanna of the protected area were not recognized by the local people. These orchids were absent from the immediate area (farmlands) of local people probably because their habitat has been modified by logging, shifting cultivation and other agriculture activities. AssÉDÉ et al. (2012) have reported that several native species disappeared from surrounding areas of the reserve because of anthropogenic activities and now only remained in the protected zones. Nevertheless, the remaining gallery forests in the farmlands still conserve their original vegetation and some orchid species of gallery forests can be collected. As reported by GOUWAKINNOU et al. (2011), the importance of orchid species for the local population may also depend on their occurrence in the area. For example, high cultural importance of Calyptrochilum christianum, Eulophia guineensis and Nervilia kostchyi could be attributed to their occurrence and abundance in gallery forests of unprotected areas. Statistically, TARdío \& PARDO-DE-SAntayana (2008) found a positive and significant correlation between the number of uses and the frequency of citation of the species by local communities. According to the authors, the more versatile a plant is, the more widespread is its usefulness. However, previous studies have highlighted that plant species are not always valued equally by local communities (Vodounê et al. 2009, Gouwakinnou et al. 2011) and the relationship between local availability and use values was found to be weak in some cases (CunHa \& Albuquerque 2006, LuCENA et al. 2007).

Interestingly, the local name of recorded orchid species varies globally from one ethnic group to another. The name of the species in the local language may vary according to its uses. Sometimes when a type of use is common to two ethnic groups, then the species may have the same name at the level of the two social groups (FANDOHAN et al. 2010, GouWAKINNOU et al. 2011).

It emerged from the survey that orchids were very little known and most used for medicinal and spiritual purposes. This finding is in accordance with KASULO et al. (2009) who reported that wild orchids in Malawi were more widely used in medicine. However, this restricted knowledge of orchids was very deep within the Waama and Gourmantché groups. This could be linked to their proximity to the reserve and the limited influence of modern habits on these socio-cultural groups. Indeed, the old Waama and Gourmantché women were shown to have an extensive medicinal knowledge of orchid uses. These uses were mainly related to infant issues. For example, C. christianum, the most common orchid species and widely known by the respondents, was used by $21 \%$ of the respondents to accelerate the walking stage for kids. The fact that only the old women had this knowledge could lead to a break in indigenous knowledge transfer to new generations. This result was also reported by FANDOHAN et al. (2010) with regard to tamarind uses. The high rural exodus observed in the locality (CENAGREF, 2016) due to extreme poverty, could justify this finding. However, orchids were also known for their spiritual properties and this knowledge seems to be related to old men. Thus, a specialization in use of orchid species can be assumed inside the communities even if the results did not show a significant difference of knowledge on orchid species between sexes.

While orchids were not really valued in the study area, they significantly contribute to the income of the local population in other parts of the world. NyOMORA (2005) reported that orchids were used by the populations of southern highlands of Tanzania as vegetables in place of meat. This trend in food use is reinforced by MENZEPOH (2011) in Cameroon where the tuber of Habenaria keayi Summerh. and the roots of H. zambesina Rchb.f. were used for food (JosHI 2009, KASUlO et al. 2009). During the survey, the low attention paid by the local populations around the PBR to orchids revealed that they do not even know that some orchid species produce flowers important for their identification. In India, the extreme beauty of the orchid flowers has made them widely used in the decoration of places of worship and other festivities. Although not properly measured in this study, the contribution of the orchids to the income of households living around the PBR seems insignificant. In contrast, the orchid species were reported to contribute considerably (up to $\$ 20$ per month) to the income of the rural Malawians (KASULO et al. 2009). It may be necessary to document additional information on the non-trade of the wild orchids as reported by the respondents, through field surveys of markets and interviews with local plant healers. 


\subsection{Implications for the Conservation and Management}

The low knowledge of local populations around the PBR of orchids may prevent their commercialization in the study area and could be positive for their conservation. However, the beauty of the flowers of some of these orchids could be an asset in promoting these species in aesthetics and decoration after understanding and promoting their domestication. In fact, compared with the economic importance of orchids in other parts of the world (DAVENPORT \& NDANGalasI 2003, Subedi et al. 2013, Phelps \& Webb 2015), the orchids in the study area are at this point relatively underutilized. A high commercial potential exists for several Habenaria and other orchid species (SingH \& DugGal 2009, Hossain 2011, PANT 2013) that can be used to improve the livelihoods of local people. However, there is needed to first assess the population dynamics of the relevant orchid species to determine their suitability for domestication in the study area. Trade in wild harvested orchids may threaten the local biodiversity through overexploitation (HEMLEY 1994, DavenPort \& Ndangalasi 2003, Subedi et al. 2013). However, sustainable exploitation of orchids could be expected following a successful domestication of the orchid species.

Habitat destruction was also an important factor threatening orchid species in the study area (AsséDÉ et al. 2012). According to the New York Natural Heritage Program, when rare plants are protected, distinctive populations of species are preserved along with their genetic variation within their natural habitats. Because orchids are the most evolved of all flowering plants, they are very site-specific and need optimum conditions to thrive in a given ecosystem. It is therefore crucial to put effort in conservation and rehabilitation of disturbed savanna ecosystems on farmland around the protected areas. The diversity of traditional uses and knowledge recorded during the study should be considered when designing regional management strategies. For example, because the Gourmantché women assigned a high medicinal value to orchid species, they should be involved in strategies aimed at selection, conservation and domestication of rare genotypes as well as most used orchid species. At the same time, they should be involved in domestication, improvement programs as well as identification of potential market niches for the orchid species development in Benin. Establishment of small-scale sustainable orchid breeding enterprises could be a valuable alternative for the production of medicinal orchids for local communities.

\section{CONCLUSION}

Twenty nine different types of use of orchids were reported for traditional medicine, food, veterinary and spiritual purposes. From the total respondents, $56.25 \%$ knew and used at least one of the recorded orchid species. H. filicornis, $P$. paludosa, $P$. caudatus and $C$. arcuata were not identified by local people. The ethnic group and the age were the two main factors which affected the knowledge of orchid species. The medicinal and spiritual uses had the highest total cultural importance index value. Old women ( $>60$ years) from the Gourmantché and Waama ethnic groups had more knowledge of the medicinal uses of orchids while the men were more focused on the veterinary uses. In view of their conservation, it is crucial that traditional ethnic knowledge of orchids should be preserved. In future, research should be focused on the domestication potential and enterprise development of orchid species for their sustainable use.

\section{ACKNOWLEDGEMENTS}

We acknowledge funding from Rufford Foundation through Rufford Small Grants for Nature Conservation (fellowship number 16855-1 for E.P.S. Assédé). E.P.S. Assédé was further supported by fellowships from University of Pretoria Postdoctoral Fellowship Program. We also thank the staff of the Pendjari Biosphere Reserve for logistical support during this study. Most importantly, we are grateful to the field guides and farmers of the villages surrounding the reserve, who collaborated during data collection. Voucher specimens were provided for most species and deposited at the National Herbarium of Benin.

\section{REFERENCES}

AmbÉ GA \& Malaisse F (2000): Diversité des plantes médicinales et ethnotaxonomie en pays malinké de Côte d'Ivoire, $2 \mathrm{p}$.

Abe R \& Ohtani K (2013): An Ethnobotanical Study of Medicinal Plants and Traditional Therapies on Batan Island, the Philippines. J. Ethnopharmacol. 145:554-565. DOI:10.1016/j.jep.2012.11.029.

ACHARYA K P \& ROKAYA M B (2010): Medicinal Orchids of Nepal: Are They Well Protected? Our Nature 8:82-91.

Acharya K P, VetaAs O R \& Birks J B (2011): Orchid Species Richness Along Himalayan Elevation Gradients. J. Biogeogr. 38:1821-1833.

Adégbidi A, Ahohounkpanzon M, Adjovi E, HoudeKON V, DJoi D \& Fagnisse S (1999): Profil de Pauvreté et d'Inégalité au Bénin. Cahier de recherche 00:01.

AKoÈgninou A, van der Burg W J \& VAN Der Maesen L J G (2006): Flore Analytique du Bénin. Backhuys Publishers, Wageningen, Netherland.

Assédé E P S, Duagoun C A M S, Azihou F A, Gogan Y S C, Kouton M D, Adomou A C, Geldenhuys C J \&. SinSIN B A (2017): Efficiency of conservation areas to protect orchid species in Benin, West Africa. Manuscript submitted to South African J Bot. Available at http://www.evise.com/ evise/faces/pages/navigation/NavController.jspx?JRNL_ $\mathrm{ACR}=\mathrm{SAJB}$.

AsséDÉ P E S (2014): Ecology of Plant Communities in the Biosphere Reserve of Pendjari, BENIN (West Africa). Doctoral Dissertation, University of Abomey-Calavi, AbomeyCalavi, Republic of Benin.

Assédé E P S, Adomou A C \& Sinsin B (2012): Secondary Succession and Factors Determining Change in Soil Condition from Fallow to Savannah in the Sudanian Zone of Benin. Phytocoenologia 42: 181 - 189.DOI:10.1127/0340269X/2012/0042-0506.

Assogbadjo A E (2006): Importance Socio-Economique et Etude de la Variabilité Ecologique, Morphologique, Génétique et Biochimique du Baobab (Adansonia digitata L.) au Bénin. Doctoral Dissertation, Faculteit Bio-Ingenieur-swetenschappen. Universiteit Gent, Gent, Belgium.

Assogbadjo A E, Glèlè Kakaï R, Chadaré F J, ThomSon L, Kyndt T, Sinsin B \& Van Damme P (2008): Folk Classification, Perception, and Preferences of Baobab Pro- 
ducts in West Africa: Consequences for Species Conservation and Improvement. Econ. Bot. 62:74-84. DOI:10.1007/ s12231-007-9003-6.

Avocèvou C (2011): Etude de la Viabilité des Populations de Pentadesma butyracea Sabine et de leur Socio-Economie au Bénin. Doctoral Dissertation, Department of management of Naural Resources, University of Abomey-Calavi, Abomey-Calavi, Republic of Benin.

Barrow E, Clarke J, Grundy I, Kamugisha J R \& TesseMA Y (2002): An Analysis of Stakeholder Power and Responsibilities in Community Involvement in Forest Management in Eastern and Southern Africa. IUCN-EARO, Nairobi.

Bayman P, Mosquera-Espinosa A T, Saladini-Aponte C M, Hurtado-Guevara N C \& Viera-Ruiz N L (2016): Age-Dependent Mycorrhizal Specificity in an Invasive Orchid, Oeceoclades maculata. Am. J. Bot. 103:1880-1889. DOI:10.3732/ajb.1600127.

Behera D, Rath C C, Tayung K \& Mohapatra U B (2013): Ethnomedicinal Uses and Antibacterial Activity of Two Orchid Species Collected from Similipal Biosphere Reserve Odisha, India. J. Agricultural Technol. 9:1269-1283.

Berhaut J (1967): Flore du Sénégal, 2nd edition, Clair Afrique, Dakar, Senegal.

Bless C, Higson-Smith C \& Sithole S L (2013): Fundamentals of Social Research Methods: An African Perspective, 5th edition, Juta Publication, Cape Town, South Africa.

Cakova V (2013): Contribution à l'Etude Phytochimique d'Orchidées Tropicales : Identification des Constituants d'Aeridesrosea et d'Acamperigida : Techniques Analytiques et Préparatives Appliquées à Vanda coerulea et Vanda teres. Doctoral Dissertation, Université de Strasbourg, Strasbourg, France.

CENAGREF (2016): Plan d'Aménagement et de Gestion Participative de la Réserve de Biosphère de la Pendjari. Programme d'appui aux Parcs de l'Entente, Composante 2. Cotonou, Benin.

Cunha L \& Albuquerque U (2006): Quantitative Ethnobotany in an Atlantic Forest Fragment of Northeastern Brazil-Implications to Conservation. Environ. Monit. Assess. 114:1-25. DOI:10.1007/s10661-006-1074-9.

Dash P K, Sahoo S \& Bal S (2008): Ethnobotanical Studies on Orchids of Niyamgriri Hill Ranges, Orissa, India. Ethnobot. Leafl. 12:70-78.

Davenport T R B \& NdAngalasi H J (2003): An Escalating Trade in Orchid Tubers Across Tanzania's Southern Highlands: Assessment, Dynamics and Conservation Implications. Oryx 37:55-61. DOI: https://doi.org/10.1017/ S0030605303000127.

De Caluwé E, De Smedt S, Assogbadjo A E, Samson R, Sinsin B \& Van Damme P (2009): Ethnic Differences in Use Value and Use Patterns of Baobab (Adansonia digitata L.) in Northern Benin. Afr. J. Ecol. 47: 433-440. DOI:10.1111/ j.1365-2028.2008.01023.x.

Deb C R, Deb M S, Jamir N S \& Imchen T (2009): Orchids in Indigenous System of Medicine in Nagaland, India. Pleione 3: 209-211.

Djossa B A, Fahr J, Wiegand T, Ayihouénou B E, KalKo E E \& Sinsin B A (2008): Land Use Impact on Vitellaria paradoxa C.F. Gaertn. Stand Structure and Distribution Patterns: A Comparison of Biosphere Reserve of Pendjari in Atacora District in Benin. Agroforest. Syst. 72:205-220. DOI:10.1007/s10457-007-9097-y.

Dressler R L (2005): How Many Species? Selbyana 26:155-158. URL: http://www.jstor.org/stable/41760186.

EKuÉ M R M (2009): Ethnobotanical Knowledge, Morphological Variation and Genetic Diversity of Ackee (Blighia sapida K.D. Koenig) in Benin. Doctoral Dissertation, University of Göttingen, Göttingen, Germany.

FANDOHAN A B (2011): Conservation Biology of Tamarindus indica (Fabaceae) in Benin, West Africa. Doctoral Dissertation, Department of management of Natural Resources, University of Abomey-Calavi, Abomey-Calavi, Republic of Benin.

Fandohan B, Assogbadjo A E, Glèlè Kakaï R, Kyndt T, De Caluwé E, Codjia J T C \& Sinsin B (2010): Women's Traditional Knowledge, Use Value and the Contribution of Tamarind (Tamarindus indica L.) to Rural Households' Cash Income in Benin. Econ. Bot. 64:248-259. DOI:10.1007/ s12231-010-9123-2.

Gadgil M, Seshagiri Rao R P, Utkarsh G, Pramod P \& Chatre A (2000): New Meanings for Old Knowledge: the People's Biodiversity Registers Programme. Ecol. Appl. 10:1307-1317. DOI:10.1890/10510761(2000)010[1307:N MFOKT]2.0.CO;2.

Gaoue O G (2008): Assessing the Impact of Bark and Foliage Harvest on Khaya senegalensis (Meliaceae) in Benin, West Africa. Doctoral Dissertation, University of Hawaii, Hawaii, USA.

Gouwakinnou N G (2011): Population Ecology, Uses and Conservation of Sclerocarya birrea (A. Rich.) Hochst (Anacardiaceae) in Benin, West Africa. Doctoral Dissertation, Department of management of Natural Resources, University of Abomey-Calavi, Abomey-Calavi, Benin Republic.

Goumakinnou G N, Lykke A M, Assogbadjo A E \& SinSIN B (2011): Local Knowledge, Pattern and Diversity of Use of Sclerocarya birrea. J. Ethnobiol. Ethnomed. 7:8. DOI:10.1186/1746-4269-7-8.

Grassi F, Imazio S, Gomarasca S, Citterio S \& Aina R (2004): Population Structure and Genetic Variation Within Valeriana wallrothii Kreyer in Relation to Different Ecological Locations. Plant Sci. 166:1437-1441. DOI:https://doi. org/10.1016/j.plantsci.2004.01.014.

Gravendeel B, Smithson A, Slik F J W \& Schuiteman A (2004): Epiphytism and Pollinator Specialization: Drivers for Orchid Diversity? Philoso. T. Roy. Soc. B. 359:1523-35. DOI:10.1098/rstb.2004.1529.

Guedje N M, Lejoly J, Nkongmeneck B A \&. Jonkers W B J (2003): Population Dynamics of Garcinia lucida (Clusiaceae) in Cameroonian Atlantic Forests. Forest Ecol. Manag. 177:231-244. DOI: https://doi.org/10.1016/S03781127(02)00444-9.

Hamisy W C (2007): Development of Conservation Strategies for the Wild Edible Orchid in Tanzania. Progress report for The Rufford Small Grants Foundation. London: The Rufford Foundation. National Plant Genetic Resources Centre, Arusha.

Hemley G (1994): International Wildlife Trade: A CITES Source book. Island Press, Washington, US.

HiLb J M (2011): Negative Binomial Regression, 2nd edition. Cambridge University Press, New York, US. 
Hossain M M (2011): Therapeutic Orchids: Traditional Uses and Recent Advances an Overview. Fitoterapia 82:102-140. DOI: https://doi.org/10.1016/j.fitote.2010.09.007.

Houessou L G, Lougbegnon T O, Gbesso F G H, AnAGONOU L E S \& SINSIN B (2012): Ethno-botanical Study of the African Star Apple (Chrysophyllum albidum G. Don) in the Southern Benin (West Africa). J. Ethnobiol. Ethnomed. 8:40. DOI: 10.1186/1746-4269-8-40.

Huynh T T, Thomson R, Mclean C B \& Lawrie A C (2009): Functional and Genetic Diversity of Mycorrhizal Fungi from Single Plants of Caladenia formosa (Orchidaceae). Ann. Bot-London 104: 757-765. DOI: https://doi. org/10.1093/aob/mcp153.

Jalal J S, Kumar P \&. Pangtey Y P S (2008): Ethnomedicinal Orchids of Uttarakhand, Western Himalaya. Ethnobot. Leafl. 12:1227-30.

JoHnson S D (1996): Bird Pollination in South African Species of Satyrium (Orchidaceae). Plant Syst. Evol. 203:9198. DOI:10.1007/BF00985239.

Johnson K A (2012): A Survey of the Orchid Diversity (Orchidaceae) in Sainte Luce, Petriky, and Mandena (Southeast Madagascar). Independent Study Project (ISP) Collection. Paper 1264.http://digitalcollections.sit.edu/isp_collection/1264

Joshi G, Tewari L M, Lohani N, Upreti K, Jalal J S \& TEWARI G (2009): Diversity of Orchids on Uttarakhand and their Conservation Strategy with Special Reference to their Medicinal Importance. Rep. Opin. 1:47-52.

JuILlET N (2006): Evolutionary Ecology of the Colourdimorphic Rewardless Orchid "Dactylorhiza sambucina". Doctoral Dissertation, Université de Lausanne, Lausanne, Switzerland.

Kant R, Verma J \& Thakur K (2012): Distribution Pattern, Survival Threats and Conservation of 'Astavarga' Orchids in Himachal Pradesh, Northwest Himalaya. Plant Arch 12:165-168.

Kasulo V, Mawabumba L \& Cyr M (2009): A Review of Edible Orchids in Malawi. J. Hortic. Forest 1:133-139.

Koura K (2013) : Gestion Durable des Parcs à Parkia biglobosa (Jacq.) R. Br. du Nord-Bénin (Afrique de l'Ouest): Ethnobotanique, Structure, Caractéristiques Physico-Chimique et Génétique. Doctoral Dissertation, Department of management of Natural Resources, University of AbomeyCalavi, Abomey-Calavi, Republic of Benin

Leakey R R B, Fondoun J M, Atangana A \& Tchoundjeu Z (2000): Quantitative Descriptors of Variation in the Fruits and Seeds of Irvingia gabonensis. Agroforest. Syst. 50:4758. DOI:10.1023/A:1006434902691.

LEE I Y (2011): In Vitro Culture and Germination of Terrestrial Asian Orchid Seeds. In Plant Embryo Culture: Methods and Protocols, edited by T. A. Thorpe and E. C. Yeung, pp. 53-62. Humana press, New York, NY.

LisowsKi S (2009): "Flore (Angiospermes) de la République de Guinée. Première Partie (Texte).” Scr. Bot. Belg. $41: 1-517$.

Lucena R, Araujo P \& Albuquerque U (2007): Does the Local Availability of Woody Caatinga Plants (Northeastern Brazil) Explain Their Use Value? Econ. Bot. 61:347-361. DOI:http://dx.doi.org/10.1663/0013-0001(2007)61[347:DT LAOW]2.0.CO;2.

Martin M G (2000): Définition, Mesure et Appréhension Globale de la Pauvreté: cas du Bénin. Paper Presented at Conférence de l'Association internationale pour la statistique officielle (AISO), Montreux, Suisse.

Martins J D \& Johnson S D (2007): Hawkmoth Pollination of Aerangoid Orchids in Kenya, with Special Reference to Nectar Sugar Concentration Gradients in the Floral Spurs. Am. J. Bot. 94: 650-659. DOI:10.3732/ajb.94.4.650.

Medhi R P, Chakrabarti S (2009): Traditional Knowledge of NE People on Conservation of Wild Orchids. India J. Tradit. Know. 8:11-16.

Menzepoh S B (2011): Les Orchidées Comestibles chez le Peuple Bagam, au Cameroun. Biotechnol. Agron. Soc. Environ. 15:509-514.

Muok B O (2005): Ecophysiological Studies of Sclerocarya birrea (A. Rich) Hochst. as Genetic Resource for Poverty Alleviation in Arid and Semi-arid Areas of Africa. Doctoral Dissertation, Kyoto Prefectural University, Kyoto, Japan.

Nacoulma B M (2012): Dynamique et Stratégies de Conservation de la Végétation et de la Phytodiversité du Compolexe Ecologique du Parc National du W du Burkina Faso. Doctoral Dissertation, University of Ouagadougou, Ouagadougou, Burkina Faso.

Newman B (2009): Orchids as Indicators of Ecosystem Health in Urban Bushland Fragments. Doctoral Dissertation, Murdoch University, Murdoch, Australia.

Nyomora A M S (2005): Distribution and Abundance of the Edible Orchids of the Southern Highlands of Tanzania. Tanz. J. Sci. 31:45-54.

OuÉDraogo O (2009): Phytosociologie, Dynamique et Productivité de la Végétation du Parc National d'Arly (Sud-Est du Burkina Faso). Doctoral Dissertation, University of Ouagadougou, Ouagadougou, Burkina Faso.

Pant B (2013): Medicinal Orchids and their Uses: Tissue Culture a Potential Alternative for Conservation. Afr. J. Plant Sci. 7:448-467. DOI: 10.5897/AJPS2013.1031.

Pant B, Raskoti B B (2013): Medicinal Orchids of Nepal, Himalayan Map House Pvt. Ltd, Kathmandu, Nepal.

Parrotta J A \& Trosper R L (2012): Traditional Forest-Related Knowledge: Sustaining Communities, Ecosystems and Biocultural Diversity. World Forest Series, vol. 12. Springer Science \& Business Media, New York.

Pemberton R W, Collins T M \& Koptur S (2008): An Asian Orchid, Eulophia graminea (Orchidaceae: Cymbidieae), Naturalizes in Florida. Lankesteriana 8:5-14.

Peter C I \& Johnson S D (2014): A Pollinator Shift Explains Floral Divergence in an Orchid Species Complex in South Africa. Ann. Bot. 113:277-288. DOI:https://doi. org/10.1093/aob/mct216.

Phelps J \& WebB EL (2015): "Invisible" wildlife Trades: Southeast Asia's Undocumented Illegal Trade in Wild Ornamental Plants. Biol. Conserv. 186:296-305. DOI :https:// doi.org/10.1016/j.biocon.2015.03.030.

Pieroni A, Ibraliu A, Abbasi A M \& Papajani-Toska V (2015): An Ethnobotanical Study Among Albanians and Aromanians Living in the Rraicë and Mokra areas of Eastern Albania. Genet. Resour. Crop. Evol. 62:477-500. DOI:10.1007/s10722-014-0174-6.

R Core Team (2014): R: A language and Environment for Statistical Computing.[web page]. URL:http://www.R-project.org/. Accessed on January 1, 2015. 
Reimer J K \& Walter P (2013): How Do You Know it When You See it? Community-Based Ecotourism in the Cardamom Mountains of Southwestern Cambodia. Tourism Manag. 34:122-132. DOI:https://doi.org/10.1016/j.tourman.2012.04.002.

SANFORD W W (1971): The Flowering Time of West African orchids. Bot. J. Linn. Soc. 64:163-181. DOI:10.1111/j.1095-8339.1971.tb02143.x.

Singh A \& DugGal S (2009): Medicinal Orchids-an Overview. Ethnobot. Leafl. 13:351-63.URL: http://opensiuc.lib. siu.edu/ebl/vol2009/iss3/3.

Subedi A, Kunwar B, Choi Y, Dai Y, van Andel T, Chaudhary RP, de Boer HJ \& Gravendeel. B (2013): Collection and Trade of Wild-Harvested Orchids in Nepal. J. Ethnobiol. Ethnomed 9:64. DOI: 10.1186/1746-4269-964.

Sujarwoa W, Canevab G (2016): Using Quantitative Indices to Evaluate the Cultural Importance of Food and Nutraceutical Plants: Comparative Data from the Island of Bali (Indonesia). J. Cult. Herit. 18:342-348. DOI:https://doi. org/10.1016/j.culher.2015.06.006.

Tardío J \& Pardo-De-Santayana M (2008): Cultural Importance Indices: A Comparative Analyzis Based on the Useful Wild Plants of Southern Cantabria (Northern Spain). Econ. Bot. 62:24-39. DOI:10.1007/s12231-007-9004-5.

Tiwari A P, Joshi B, Ansari A A (2012): Less Known Ethnomedicinal Uses of Some Orchids by the Tribal Inhabitants of Amarkantak Plateau, Madhya Pradesh, India. Nat. Sci. 10:33-37. URL :http://www.sciencepub.net/nature.

Ver Hoef J M, Boveng PL (2007): Quasi-Poisson vs. negative binomial regression: how should we model overdispersed count data? Ecology 88:2766-2772.

Vihotogbé R, Glèlè KaKaï R, Bongers F, van Andel T, van Den Berg R G, Sinsin B \& Sosef M S M (2014): Impacts of the Diversity of Traditional Uses and Potential Economic Value on Food Tree Species Conservation Status: Case Study of African Bush Mango Trees (Irvingiaceae) in the Dahomey Gap (West Africa). Plant Ecol. Evol. 147:109125. DOI: https://doi.org/10.5091/plecevo.2014.789.

Vodouhê F, Coulibaly O, Greene C \& Sinsin B (2009): Estimating the Local Value of Non-Timber Forest Products to Pendjari Biosphere Reserve Dwellers in Benin. Econ. Bot. 63:397-412. DOI:10.1007/s12231-009-9102-7.

Vogt-Schilb H, Munoz F, Richard F \& Schatz B (2015): Recent Declines and Range Changes of Orchids in Western Europe (France, Belgium and Luxembourg). Biol. Conserv. 190:133-141. DOI:https://doi.org/10.1016/j.biocon.2015.05.002. 